\title{
Estate Planning and Wills Across Borders: Sometimes a Quagmire in the Making
}

\section{P.E.R}

Pioneer in peer-reviewed, open access online law publications

Author

Eben $\mathrm{Nel}$

\section{Affiliation}

Nelson Mandela University

South Africa

Email eben.nel@psg.co.za

Date Submission

28 May 2020

Date Revised

31 August 2021

Date Accepted

31 August 2021

Date published

13 October 2021

Editor Dr G Viljoen

How to cite this article

Nel E "Estate Planning and Wills Across Borders: Sometimes a

Quagmire in the Making" PER /

PELJ 2021(24) - DOI

http://dx.doi.org/10.17159/1727-

$3781 / 2021 / v 24 i 0 a 8396$

\section{Copyright}

DOI

http://dx.doi.org/10.17159/1727-

3781/2021/v24i0a8396

\section{Abstract}

In this article a synoptic evaluation is made in respect of the estate planning and wills of South African nationals working, investing or living in foreign jurisdictions, in the broader context of globalisation and internationalisation. Estate planners and testators may inadvertently leave family members in a financially vulnerable position or diminish family assets due to a nonappreciation of international private law. The importance of international wills, the role of testamentary trusts, and the potential impact and reciprocity of international instruments are considered. The most applicable Hague Conventions and the EU Succession and Matrimonial Property Regulations are discussed in an attempt to give an overview of the current legal position. In discussing the role of international private law, its practical application is illustrated by way of reference to a few jurisdictions popular among South Africans with multijurisdictional estates, namely Malta, Portugal, the Netherlands and the United Kingdom. Although there may be more popular emigration jurisdictions amongst South Africans, this contribution focusses on the South African who lives, works and plays in a European context, without necessarily cutting his or her ties with the homeland. Not all attempts to harmonise wills, deceased estates, succession and matrimonial property regimes have been met with the same levels of enthusiasm by the international community. Contributing hereto may be the fact that fiduciary law deals with sensitive and very personal aspects of individuals and is closely linked to the different worldviews of communities. It is argued that not only fiduciary advisers and will drafters, but also attorneys and notaries involved with prenuptial agreements, should be proficient in the workings and implications of the applicable international instruments. Lastly, an argument is made for more pragmatic and commercial style thinking in the arena of fiduciary law.

\section{Keywords}

Wills; testamentary trusts; international estate planning; private international law; Regulation on Succession; Regulation on Matrimonial Property; section 3 bis of the Wills Act. 


\section{Introduction}

Although globalisation has been described as "an international integration in commodity, capital and labour markets", ${ }^{1}$ it is much more than that. South Africa and her citizens, and not only high-net-worth families, are fully engaged in this phenomenon of interconnectedness. It has been alleged that globalisation "affects all walks of life in many different ways" and "has not produced homogeneity or standardisation in everyday life, but instead brought much difference and diversity to global society."2

A variety of reasons may lead to South Africans creating second-passport options: from being motivated by the local tax regime, empowerment policies, crime, corruption, political uncertainties or poor health and education systems, to those subscribing to the so-called flag theory, epitomised in the expression "going where you are treated the best". Diversification of jurisdiction may result in a change in tax residency or financial emigration, while certain captured assets, such as a living annuity, are left behind. ${ }^{3}$ Due to the existence of distinct succession and inheritance tax laws in different jurisdictions, the process of estate planning may be complicated by a mismatch of the factors that are used to determine tax liability. This may result in some assets being taxed more than once or not at all, with double tax agreements alleviating only some of these challenges. ${ }^{4}$ When emigrating, the impact of capital gains tax is one of the main aspects to consider when deciding on when to sell assets. When working abroad, currency issues become important, while an appreciation of the tax dispensation and issues such as estate duty in the final destination is crucial in the decision-making process. Other aspects such as trust structures, connected persons and beneficial ownership are also potential deal-breakers.

The five flags strategy is said to be a key strategy in surviving and prospering globally. It has to do with internationalising your life in the form of residency, citizenship, banking, assets and business. The focus in this

Eben Nel. B Juris (UPE) LLB (UNISA) LLM (UPE) LLD (NMMU) PD Fin Planning (UFS). Research Associate in the Department of Mercantile Law, Nelson Mandela University. Email: eben.nel@psg.co.za. ORCID: https://orcid.org/0000-0003-1386007X.

1 Geçer Practical Matter Test 2; WTO World Trade Report 2008. Globalisation is often discussed in terms of economic, political and socio-cultural contexts.

Faulconbridge and Beaverstock "Globalization" 340.

The capital in a living annuity may not be taken, but the investor may opt to have the income paid in his new location.

For an extensive discussion on the different tax consequences, consult Ernst \& Young Worldwide Estate and Inheritance Tax Guide. 
article will be on the impact of internationalisation on estate planning and succession. The concept of asset protection is often associated with the increase of private wealth, but in the context under discussion it deals primarily with the defence mechanism of protecting what the individual family group already has or may acquire through business ventures or inheritances. The theory of diversifying one's life into separate jurisdictions may not be convincing for everyone, but the potential advantages of the multiple jurisdictional estate cannot be disputed. Due to the millions of socalled international couples - in the EU alone an estimated 16 million couples - people are often forced by circumstances to operate under multiple flags. ${ }^{5}$ Internationalising your life, as intended by the five-flag strategy, is a long, ongoing process, preferably evolving with the needs and choices of the broader family group. It has been called a wealth and estate planning process on steroids. There are some pushbacks, however, in the aggressive marketing of foreign jurisdictions, as EU member states have been requested to phase out all investment-based citizenship and residency schemes as soon as possible in an attempt to crack down on those who employ tax avoidance strategies. ${ }^{6}$

The focus in this article is on South African citizens working, investing or living in foreign jurisdictions with the intention of acquiring elsewhere a second passport, dual citizenship or permanent residency. ${ }^{7}$ Three aspects that may have an impact on international families with a South African connection will be discussed, namely the internationalisation of wills, the role of trusts in international wills, and the potential impact of international instruments, particularly in terms of the European Union (EU) Succession Regulation $^{8}$ and the EU Matrimonial Property Regulations. ${ }^{9}$ Although

5 See Swire 2019 Step Journal 30-31.

$6 \quad$ In March 2019 the European Parliament voted in favour of such intervention. Cyprus has already introduced a variety of amendments to its investment programme to strengthen aspects of transparency, governance and security.

7 South African citizens may have a foreign passport without forfeiting their South African citizenship but may not use the foreign document to enter or exit the Republic. The foreign passport may be used only to travel abroad. See s 26B of the South African Citizenship Act 88 of 1995 (as amended); South Africa - New York Date Unknown http://www.southafrica-newyork.net/homeaffairs/dualcitinfo.htm.

8 EU Council Regulation No 650/2012 (2012), adopted on 7 June 2012, Ch IV on Jurisdiction, Applicable Law, Recognition and Enforcement of Decisions and Acceptance and Enforcement of Authentic Instruments in Matters of Succession and on the Creation of a European Certificate of Succession (the EU Succession Regulation).

$9 \quad$ These include, for the purposes of this article, both the EU Council Regulation No 2016/1103, Implementing Enhanced Cooperation in the Area of Jurisdiction, Applicable Law and the Recognition and Enforcement of Decisions in Matters of Matrimonial Property Regimes (2016) and EU Council Regulation No 2016/1104, Implementing Enhanced Cooperation in the Area of Jurisdiction, Applicable Law and 
permanent relocation to Oceania, Canada and the United States are popular amongst many South Africans, the research focussed on a few jurisdictions in the European region where many South Africans live, work and play without necessarily cutting their ties with the homeland. In the evaluation of various international instruments, including recent EU regulatory initiatives, the applicability of these instruments will be illustrated by way of reference to a few affected jurisdictions popular among South Africans with multi-jurisdictional estates, namely Malta, Portugal, the Netherlands and the United Kingdom. ${ }^{10}$

\section{The internationalisation of wills}

The question of multiple wills arises whenever a family owns assets in more than one jurisdiction - whether due to offshore investments, inheritances or accumulation - while working overseas. A variety of aspects should be considered when a testator opts for one will dealing with worldwide assets, or for a different will for each jurisdiction. To name but a few: the practicality of one executor having to deal with the different estates by way of agents as opposed to several different executors; the potential of conflicting clauses in different wills; the risk of inadvertently revoking a will while dealing with assets in another jurisdiction; or the difference in language, culture, legal terminology or legal principles, such as matrimonial property regimes or forced heirship rules. There is a risk that a will drafted in one jurisdiction may not be recognised as valid elsewhere, with some jurisdictions having automatic revocation by divorce or by marriage or civil partnership. ${ }^{11}$ In addition, the effect of a prenuptial agreement in a foreign

the Recognition and Enforcement of Decisions in Matters of the Property Consequences of Registered Partnerships (2016), both of which were adopted on 24 June 2016 (the Matrimonial Property Regulations). See Nel 2018 TSAR 601-612 for a discussion on the impact of the EU Succession Regulation.

As far as internal legislative and cultural references are concerned, a reference to the United Kingdom is focussed on the position in England and Wales only, excluding Scotland and Northern Ireland.

11 In the UK an individual's existing will is automatically revoked by marriage or civil partnership, except if it is clearly indicated in the will that it was made "in contemplation of marriage", while a testamentary disposition in favour of a spouse in the Netherlands becomes extinguished by divorce or legal separation, in terms of art 4:52 Burgerlijk Wetboek (BW), unless the contrary may be deduced from the last will itself. See s 2B of the Wills Act 7 of 1953 for the effect of divorce or annulment of marriage on a will in South Africa, and ss 14(2)(a) and 22(2)(c) of the Administration of Estates Act 66 of 1965 for the prescribed procedures. In the recent judgment of JW v Williams-Ashman 20204 SA 567 (WCC), an application for an order declaring S $2 \mathrm{~B}$ inconsistent with and/or contrary to ss $25(1)$ and 34 of the Constitution of the Republic of South Africa, 1996 was dismissed. 
jurisdiction should be considered in the case of a potential multijurisdictional estate.

To illustrate: a couple that married in South Africa in terms of an antenuptial agreement and decided to move to England or Wales must be made aware of the fact that such agreements entered into in South Africa are generally not binding in England and Wales. This principle has recently been relaxed where it can be proved that the parties freely entered into the agreement; that the parties had full appreciation of the implications of the agreement at the time they entered into it; and that it is fair to uphold the agreement in the circumstances. ${ }^{12}$ It did become a requirement, however, that a qualifying nuptial agreement must have been reached following a full exchange of financial disclosure, following the receipt of independent legal advice. ${ }^{13}$ Because it may be difficult for a surviving spouse to prove this many years later, a post-nuptial agreement on the same terms in the new jurisdiction may be a solution.

The following should be considered when decisions are taken about the drafting of one or more wills: the locality of the assets; the taxability of the property in each jurisdiction; and international legislation, such as the Hague Convention on Testamentary Dispositions ${ }^{14}$ and the EU Succession Regulation. ${ }^{15}$ It seems as if, in general, conflicting rules in international treaties should take priority over national legislation. ${ }^{16}$ Ultimately, before any important decision in the estate planning process is taken, including the drafting of a will or wills, a comprehensive estate plan or at least an estate evaluation should be prepared, taking into account all applicable jurisdictions and other relevant aspects.

12 See Radmacher $v$ Granatino [2010] UKSC 42. In 2014 the Law Commission of England and Wales recommended that prenuptial agreements be made binding in certain circumstances - a so-called qualifying nuptial agreement - which resulted in a Private Member's Bill being introduced in 2017, which intended to make provision for binding pre-nuptial and post-nuptial agreements. The Bill did not make it past its second reading. Compare Versteegh v Versteegh [2018] EWCA Civ 1050; Brack v Brack [2018] EWCA Civ 2862.

14 Hague Convention on the Conflict of Laws Relating to the Form of Testamentary Dispositions (1961) (Hague Convention on Testamentary Dispositions). See para 7 below.

15 EU Succession Regulation. See Phipps "Wills and Estates" for more on multiple wills.

16 See Schulze 2001 CILSA 45-47 for more on the application of different conflict rules in competing jurisdictions, which may lead to different results. 


\section{The role of trusts in wills}

A trust or trusts may fulfil an important role in at least two of the five elements of flag theory, namely assets and business activities. Due to the potential protection trusts and similar institutions can grant estate planners, those familiar with these structures due to their country of origin will often consider it as part of internationalising their estates. ${ }^{17}$

The creation of a testamentary trust by a South African testator benefitting minor heirs in a foreign jurisdiction may present a challenge. A further complication may be the nomination of trustees with offshore domiciles. The fact that South African trusts are prohibited by exchange control regulations from directly owning international assets makes offshore trusts alluring for many estate planners. ${ }^{18}$ For instance, a destination such as Mauritius may be an attractive option due to its close proximity and good regulatory systems, although tax regulations must be carefully considered. ${ }^{19}$ When distributions are made from a South African trust to beneficiaries taxable in offshore jurisdictions, the tax implications should be appreciated, and if a trust (particularly a testamentary trust) terminates automatically upon the occurrence of a certain pre-defined event, the tax consequences may be unforeseen at best and lamentable at worst.

It is unfortunate that trusts are excluded from the scope of the EU Succession Regulation ${ }^{20}$ as the inclusion of testamentary trusts would have contributed to more legal certainty for the testator who wants to make use of a trust for minor children or other beneficiaries in need of protection. ${ }^{21}$ As trusts often fulfil an important role in estate planning, particularly in respect of larger estates, it is important to investigate international law pertaining to trusts, focussing on how they dovetail with estate planning and wills.

In Maltese law a trust may be established for succession purposes and the trustees are granted the discretion to determine the identity of the

17 See Braun "Will-Substitutes" 51-77 on how trusts are utilised in estate planning processes in England and Wales.

18 See SARB Currency and Exchange Guidelines.

19 For more on Mauritian trusts and Mauritius's functionality as an offshore jurisdiction, compare Nel Business Trust 432-437, 440-441. Estate planners and trustees must be careful not to fall foul of tax regulations such as those on round-tripping and transfer pricing.

20

See para 13 of the Preamble of the EU Succession Regulation. Compare Dutta 2009 Rabel Journal 549, advising on 592 that testamentary trusts should be included in a future regulation. 
beneficiaries as well as their portion and in what manner they will benefit. ${ }^{22}$ In terms of section 7(2) of the Maltese Trust and Trustees Act, a trust may come into existence by way of a will. Trusts are not recognised In Portugal; thus, testamentary trusts as heirs will not be acknowledged. ${ }^{23}$ In the Netherlands the notion of a trust is unfamiliar and the fiducia ${ }^{24}$ prohibited, although the Dutch do make use of the testamentair bewind. ${ }^{25}$ In the United Kingdom testamentary trusts are regarded as express private trusts, transferring legal title to the trustees and the equitable interest to the beneficiaries. $^{26}$

\section{Private international law}

Under South African private international law, the choice-of-law rules as far as movables are concerned refer to the lex ultimi domicilii (domicile upon death) irrespective of where the asset is located, and the lex rei sitae regarding immovable assets. ${ }^{27}$ Historically, most European private international law instruments expressly exclude matters of succession and wills. ${ }^{28}$ However, the need to adopt harmonised European rules was not limited to the areas of choice of laws, jurisdiction, and the enforcement of judgments, but did include the cross-border administration and winding-up of deceased estates and ultimately the recognition and enforcement of wills and other succession-related deeds, including testamentary trusts. ${ }^{29}$

Dutta emphasises both the quantitative and qualitative realities of the conflict-of-laws in the area of wills and succession. ${ }^{30}$ The fact that jurisdictions differ with regard to a monist or dualist approach to the conflict of laws greatly complicates the matter. In terms of a monist or unitary approach one connecting factor is employed, such as nationality, domicile or habitual residence, irrespective of the location of the assets. The dualist approach, however, usually differentiates between movables and

Ruggeri, Kunda and Winkler Family Property and Succession 474. See the definition of "trust instrument" in s 1, as well as ss 7(1) and 3(1) of the Trust and Trustees Act 35 of 1988, ch 331 of the Laws of Malta (as amended).

Although it is possible to incorporate offshore trusts established under a foreign law in Madeira under particular circumstances, testamentary trusts will not qualify.

See art 84.3 BW on both the fiducia cum creditore and the fiducia cum amico.

See para 6 below.

See Sänchez 2015 Cuadernos de Derecho Transnational 100.

See Schulze 2001 CILSA 35.

Dutta 2009 Rabel Journal 549.

See European Commission 2005 https://eur-lex.europa.eu/legalcontent/EN/TXT/PDF/?uri=CELEX:52005DC0065\&from=en; Dutta 2009 Rabel Journal 550 .

Dutta 2009 Rabel Journal 552. 
immovables, with movables being governed by a connecting factor linked to the deceased, such as domicile, nationality or habitual residence, whereas immovables are determined by the lex rei sitae. ${ }^{31}$

Malta never had an extensive history of private international law, although detailed rules on jurisdiction and the conflict of laws on succession and matrimonial property were contained in their Civil Code. ${ }^{32}$ They joined the EU in 2004 and today abide by EU regulations. Rules of conflict-of-laws regarding succession are set out in the Civil Code of Portugal, but the Portuguese are bound by EU regulations. ${ }^{33}$ Although the Netherlands treat the EU Regulation as the only binding regulation to decide on jurisdiction, national procedural law is still, as in all EU states, relevant for determining some aspects. ${ }^{34}$ Private international law is not codified in English law and English courts follow the well-developed doctrine of referral (renvol) ${ }^{35}$

In general, the law of the testator's domicile will be applicable to movable property and the law of the lex rei sitae to immovable property. A will is interpreted by the law intended by the testator, which is presumed to be the law of his domicile at execution. ${ }^{36}$

\section{Section 3 bis of the Wills Act}

While South Africa has acceded to the 1961 Hague Convention on Testamentary Dispositions, ${ }^{37}$ it does not accept all parts thereof. In order to align itself with the Convention and private international law, the South African legislator introduced section 3 bis, implementing many of the effects of the Convention. ${ }^{38}$ In terms of subsection (1), a will shall not be invalid merely by reason of its form, if it complies with the internal law ${ }^{39}$ of the state or territory in which the will was executed (lex loci actus), or in which the

31 See Hayton 2008 DNotl, Les Successions Internationales dans I'UE 359-371. He is in favour of one lex successionis governing the whole of a deceased's estate.

32 The observance of international law became key in terms of the Constitution of Malta, 1964. See Xuereb "Constitution of Malta" 141-143.

33 Articles 62 and 63 of the Code of Civil Procedure of Portugal. Arts 59, 62, 63 and 94 of the Code of Civil Procedure deals with international jurisdiction. See Oberl (Case C-20/17) 21 June 2018 CJEU. See Coutinho and Piçarra "Portugal" 591-639.

34 Also see art $1(6)(\mathrm{g}) B W$, which still serves as a safety net.

Ruggeri, Kunda and Winkler Family Property and Succession 694.

O'Brien Conflict of Laws 582-584.

See para 7 below.

Section 3bis was inserted into the Wills Act 7 of 1953 by way of $s 2$ of the Wills Amendment Act 41 of 1965, and amended by s 6 of the Law of Succession Amendment Act 43 of 1992.

39 "Internal law" is defined in s 1 of the Wills Act 7 of 1953 as "the law of a state or territory, excluding the rules of the international private law of that state or territory". 
testator was domiciled at the time of execution or at his death (lex domicilii / lex ultimi domicilii), or was habitually resident in, or was a citizen of (lex patria / lex ultimae patria), whereas in the case of immovable property, if the will complies with the internal law of the state in which it is situated (lex rei sitae). ${ }^{40}$ These connecting factors were based on the above-named Convention, in terms whereof the formal validity of a will is favoured by referring alternatively to the different laws. ${ }^{41}$ The rules referred to above also apply with regard to testamentary dispositions that revoke previously made dispositions of a testamentary nature. ${ }^{42}$

In terms of the Wills Act, a further connecting factor of validation is compliance with the law of the state or territory in which an imposing instrument was executed, in so far as a power is exercised or a duty performed. ${ }^{43}$ Subsection (4) excludes all forms of oral wills by South African citizens, as provided for in article 10 of the Convention, while subsection 5 saves all wills which, but for section 3 bis, would have been valid in terms of the common law. ${ }^{44}$

\section{The Hague Convention on Trusts ${ }^{45}$}

The Hague Convention on Trusts ${ }^{46}$ refers to trusts as "unique legal institutions" and is aimed at establishing common provisions in the law applicable to trusts and their recognition, but has been acceded to or ratified by only a few countries, some of which are important role players in international estate planning, such as Malta, the Netherlands, Switzerland, Jersey, Guernsey and Isle of Man. ${ }^{47}$ While the United Kingdom applies the Convention by way of legislation, the United States, Cyprus and France have only signed it but have not adopted the Convention. ${ }^{48}$ Portugal did not take any action regarding this Convention. The Convention specifies the law

\footnotetext{
$40 \quad$ See Van der Merwe, Rowland and Cronje Suid-Afrikaanse Erfreg 576-584.

$41 \quad$ Article 1 of the Hague Convention on Testamentary Dispositions.

42 Article 2 of the Hague Convention on Testamentary Dispositions and s 3bis(1)(d) of the Wills Act 7 of 1953.

43 Section 3bis (1)(c) of the Wills Act 7 of 1953. Subs 3bis(1)(e) validates certain wills executed on board a vessel or aircraft.

$44 \quad$ See Van der Merwe, Rowland and Cronje Suid-Afrikaanse Erfreg 581.

45 This paragraph is based largely on an extract from Nel Business Trust 391-396, 505.

$46 \quad$ Hague Convention on the Law Applicable to Trusts and on their Recognition (1985) (the Hague Convention on Trusts), accepted on 1 July 1985.

47 Malta did not ratify the Convention but acceded to it. Accession is the process of accepting a treaty already negotiated and signed by other states. It has the same legal effect as ratification.

48 Implemented in the UK by way of the Recognition of Trusts Act, 1987. See Hansmann and Mattei 1998 NYU L Rev 436. South Africa did not participate in the development of this document as it took place during the time of its political isolation.
} 
applicable to trusts and that which governs their recognition, including testamentary trusts. ${ }^{49}$ In terms of the Convention, the settlor shall expressly or by implication determine the law by which the trust is governed, and where no applicable law has been chosen the trust shall be governed by the law it is most closely connected with, taking into consideration the place of administration, the situs of the assets, the place of residence or business of the settlor, as well as the objectives of the trust and where they are to be fulfilled. ${ }^{50}$ This rule simplifies the jurisdiction issue considerably. The Convention does not introduce the trust concept into the domestic law of non-trust states, nor does it create common rules for trust states. ${ }^{51}$ It focusses on common conflicts-of-law principles for both trust states and non-trust states ${ }^{52}$ and will apply where a matter is connected to the legal systems of more than one country.

Once the trust in question has been validly established according to articles 6 and 7 , recognition must take place, which entails that the trust must be given all those effects that the law governing the particular trust attaches to it. ${ }^{53}$ The applicable law shall govern the validity of the trust as well as its effects and administration. It shall further govern the position of the trustees regarding appointment, resignation, removal, their rights and duties, and their powers of delegation and investment. In addition, it shall regulate the duration of the trust, the accumulation of assets, the relationships between and the liabilities of the parties to the trust, its variation and termination, the distribution of assets, and the duty of the trustees to account for their administration. ${ }^{54}$ States do not, however, have to recognise a trust of which the significant elements are more closely connected to a state which does not have the institution of the trust or of this category of trust. ${ }^{55}$ Importantly, the Convention grants the settlor (the testator) unlimited freedom of choice

See Hayton et al 2007 Law of Trusts and Trustees 1256-1257.

Article 7 of the Hague Convention on Trusts.

Compare also in this regard the European Convention on the Law Applicable to Contractual Obligations (1980).

See Hayton and Underhill Law Relating to Trusts and Trustees 942.

Article 11 of the Hague Convention on Trusts.

Article 8 of the Hague Convention on Trusts.

Articles 12 and 13 of the Hague Convention on Trusts. Although a court is permitted to refuse to recognise a trust where all the elements are civilian except for the choice of a foreign trust law and foreign trustees, an Italian court approved a trust issue where all the elements were Italian except for the choice of foreign trust laws, which were Jersey and Malta. See Hayton et al 2007 Law of Trusts and Trustees 20. Compare also arts 15 and 16 on the application of the provisions of law. In terms of art 14 the Hague Convention on Trusts shall not prevent the application of rules of law more favourable to the recognition of trusts. 
of law, and if no election is made the trust is governed by the law most closely connected thereto. ${ }^{56}$

The Convention may add value to non-trust states in ensuring legal certainty to the position of trustees and beneficiaries domiciled within their borders. A non-trust jurisdiction ratifying the Convention receives a means to give effect to the operation of trusts within its borders without necessarily adopting the trust figure officially into its legal dispensation. ${ }^{57}$ Welldeveloped trust jurisdictions such as South Africa may also benefit from ratifying the Convention, as the harmonisation of the connecting factors creates more legal certainty. It may also further strengthen its international image and act as an economic stimulus. ${ }^{58}$

The applicability of the Hague Convention on Trusts for the purposes of this article can be summarised as follows: In Malta, trusts may be formed unilaterally by oral declaration or by way of a written instrument. ${ }^{59}$ Malta is a party to the Convention by accession and has incorporated the Convention into its legislation. ${ }^{60}$ Although a trust is regarded as a contract in Portuguese law, it was only in 2015 that Portugal first recognised it as a separate tax entity, referring to it as a "bespoke fiduciary structure". A trust is therefore not acknowledged and understood in the sense of a traditional trust as known in most common law jurisdictions. ${ }^{61}$ Although trusts are not recognised in the Netherlands, the Dutch do make use of a trust-like figure, called the testamentair bewind, in terms whereof the testator places the bequest under administrative control and limits the powers and rights of the heir. ${ }^{62}$ The ratification of the Convention by the non-trust Dutch jurisdiction therefore makes sense in the context of testamentary trusts. Trusts are acknowledged in the United Kingdom as legal arrangements for the management of assets - both to control and protect family assets and to

\footnotetext{
$56 \quad$ See arts 6 and 7 of the Hague Convention on Trusts.

$57 \quad$ Hayton and Underhill Law Relating to Trusts and Trustees 953, and 954 for a list of states that have signed and/or ratified and implemented the Hague Convention on Trusts.

$58 \quad$ Nel 2018 TSAR 604-605.

$59 \quad$ See ss 7(1)-(2) of the Maltese Trust and Trustees Act 35 of 1988.

60 The Recognition of Trusts Act, 1994 was followed by the Trusts and Trustees Act, 2004, which became effective in January 2005, the Trusts and Trustees (Amendment) Act XI of 2014 and amendments to the Maltese Civil Code.

$61 \quad$ Greene Trusts, Foundations and Fiduciary Structures 17-21.

62 Section 7 of Book 4 BW. For a detailed discussion on this legal structure, see Nel 2019 TSAR 713-727.
} 
pass on assets by way of a will at the death of the testator. The UK ratified the Convention after introducing the necessary legislation. ${ }^{63}$

As so few countries in Europe have signed the Convention, largely due to its common-law nature, its impact is limited, although it has contributed to the development of domestic trust laws in some civil law jurisdictions. ${ }^{64}$

\section{The Hague Convention on Testamentary Dispositions}

The signatories to the Hague Convention on Testamentary Dispositions ${ }^{65}$ desired to establish common provisions on the conflicts of laws relating to the form of testamentary dispositions. South Africa acceded to it but reserved some matters dealing with the determination of domicile, oral wills and non-succession matters. ${ }^{66}$ Most EU states have ratified the Convention except Portugal and Italy, who signed it without ratifying or acceding to it, and Malta has not taken any action. ${ }^{67}$ The United Kingdom ratified it, but not the United States.

The Convention deals with the validity of the form of testamentary dispositions including place, nationality, domicile, habitual residence and situs. It further regulates revocation and reciprocity, and specifies that the application of any of the laws declared applicable by the Convention may be refused only when they are manifestly contrary to the public order. ${ }^{68}$ Although the Convention was widely acceded to, its applicability is very limited as it deals mainly with the form of the testamentary disposition and not with other potentially problematic issues. ${ }^{69} \mathrm{~A}$ number of other initiatives in the form of international instruments also brought partial relief. ${ }^{70}$

63 Recognition of Trusts Act, 1987. Also see the Trustee Act 29 of 2000.

64 See Hayton 2016 J Priv Int L 1-25. Examples are the Netherlands and Switzerland, both of which amended their civil codes and harmonised their domestic laws with the rules of the Hague Convention on Trusts. Hague Convention on the Conflict of Laws Relating to the Form of Testamentary Disposition (1961) (Hague Convention on Testamentary Dispositions), accepted on 5 October 1961 and in force on 5 January 1964. Articles 9, 10 and 12 of the Hague Convention on Testamentary Dispositions. With a total of 42 contracting parties. See ENRWA 2010 http://www.arert.eu/IMG/pdf/etatdeslieux-2010-03-10-EN.pdf 78.

68 Article 7 of the the Hague Convention on Testamentary Dispositions.

69 Nineteen out of twenty-eight EU states have signed the Convention and seventeen have ratified or acceded to it.

70 See the Basel Convention on the Establishment of a Scheme of Registration of Wills (1972); the Hague Convention Concerning the International Administration of the Estates of Deceased Persons (1973); and the UNIDROIT Convention (1940), providing a uniform law on the form of an international will. 
The impact of the Hague Convention on Testamentary Dispositions or the lack thereof can be illustrated by some examples. According to Portuguese international private law, a will is deemed valid regarding its form if it respects the internal law applicable to the place where it was made, or the internal law applicable to the nationality of the testator. ${ }^{71}$ In Dutch law all local wills must be notarised. The Netherlands ratified the Convention while reserving oral testamentary dispositions except by a Dutch national having no other nationality (article 10). ${ }^{72}$ In terms of Dutch private international law, a will is deemed valid regarding its form if it complies with the lex loci or the law of the nationality, domicile or habitual residence of the testator, and in the case of immovable property, also the lex rei sitae. In terms of the laws of England, Wales and Scotland, movable property is governed by the law of the domicile of the testator and immovable property by the law of the jurisdiction where it is located. ${ }^{73}$ Wills executed in a foreign state are valid if the execution was in accordance with the laws of the country concerned or the laws of the country in which the testator was domiciled or habitually resident or of which the testator was a national, and in the case of immovable property, the lex rei sitae. ${ }^{74}$

\section{The Hague Succession Convention}

The Hague Succession Convention ${ }^{75}$ was signed by three states, ${ }^{76}$ but after many years is still not in force. Only the Netherlands ratified it, in 1996, but denounced it in 2014, effective 1 April 2015. South Africa was never a contracting party to the Convention. The Convention does not apply to the form of testamentary dispositions, the capacity to dispose of property upon death, or issues pertaining to matrimonial property or to property rights. It does stipulate, however, that the conflict-of-law rules for succession do not preclude the application of another law to a trust created by a testator. ${ }^{77}$ The exclusion of all aspects of matrimonial property was not well received, as

\footnotetext{
71 See ENRWA 2010 http://www.arert.eu/IMG/pdf/etatdeslieux-2010-03-10-EN.pdf 92.

72 Reserving art 10 of the Hague Convention on Testamentary Dispositions in terms of arts 4:94 and 4:95 BW. See Private Client Tax Committee The Netherlands.

73 See s 9 of the Wills Act 26 of 1837 and the Requirements of Writing Act, 1995 respectively, for procedural requirements.

74 See Wills Act 26 of 1837.

75 Hague Convention on the Law Applicable to Succession to the Estates of Deceased Persons (1989) (the Hague Succession Convention), accepted on 1 August 1989.

76 Argentina, Luxembourg and Switzerland. See Dutta 2009 Rabel Journal 552, criticising it for its complexity.

77 See art 14(1) of the Hague Succession Convention.
} 
spouses often move between states with different matrimonial property regimes. ${ }^{78}$

Due to non-participation in the Hague Succession Convention, it had no impact on the substantive law in the different jurisdictions. In Malta succession is regulated by chapter 16 of the Maltese Civil Code, ${ }^{79}$ applying a reserved portion of one third of the value of the estate in the form of a right of credit for the descendants on the estate of the first-dying. ${ }^{80}$ In Portugal the rules of succession combine both individual and family aspects, based on the principle that inheritance must ensure protection, regardless of the will of the deceased. Inheritance law is ruled largely by Book V of the Civil Code and, in the absence of forced heirs or if there are none within the limits of the quota, the testator may freely dispose by will or by contract (donations at death). ${ }^{81}$ The Dutch Burgerlich Wetboek regulates succession in the Netherlands with particular restrictions on testamentary freedom such as the rights to certain legitimate portions and other rights. ${ }^{82}$ In the United Kingdom the legislative and cultural differences between England, Wales, Scotland and Northern Ireland must be taken into consideration. England and Wales have particular legislation regulating wills and inheritances, ${ }^{83}$ Northern Ireland has its own, while Scotland has a mixed legal system with a separate and distinct legal dispensation. ${ }^{84}$

\section{The EU Succession Regulation}

The harmonisation of international private law in the EU has been bolstered by the EU Succession Regulation (also called Brussels IV), with the aim of alleviating certain issues linked to succession in the EU and the need to govern a couple's worldwide estate by way of a single will. The rules establish the competent court and the national laws applicable in case of divorce or death. This potentially avoids parallel and possibly conflicting results in different EU states. The Regulation applies to all deaths on or after

\footnotetext{
78 See Law Reform Commission Report on the Hague Convention.

79 Articles 588-816 of the Civil Code of Malta.

80 In terms of s 616 of the Civil Code of Malta, one third is set aside if there are no more than four children and half the value of the estate if there are five or more children. See arts 2028 and 1700 of the Portugese Civil Code, and arts 2022, 2134-2136 on forced heirship rules. The procedures regarding hereditary succession are regulated by art 201 of the Civil Registry Code, and the acquisition of succession by the Land Registry Code. See arts 4:63 and a 4:28 of Book 4 BW. See Filesia 2020 WPNR 184 for more on the current debate on the legitimate portion in Dutch law. Ruggeri, Kunda and Winkler Family Property and Succession 695.
} 
17 August 2015 and creates the European Certificate of Succession, ${ }^{85}$ which enables heirs, legatees and executors or administrators of deceased estates to prove their status and exercise their rights and duties in all EU countries. ${ }^{86}$

Bost refers to a number of issues that ultimately resulted in the cross-border EU Succession Regulation, namely the determination of the competent judicial system in case of the administration of multi-jurisdictional succession due to varying and conflicting connecting factors in different countries; discrepancies among the conflict-of-law rules among EU states; the limited choice-of-law options in some jurisdictions; restrictions regarding the recognition and enforcement of judgments; and administrative difficulties regarding recognition by authorities in multiple states. ${ }^{87}$

The EU Succession Regulation allows habitual residence as the single connecting factor for succession, except if the testator has elected the inheritance law of his country of nationality to be applicable. The Certificate of Succession simplifies administrative processes for heirs and administrators, while national laws concerning succession and the registration of property will remain in force. ${ }^{88}$ The Certificate shall be recognised and accepted by all member states in respect of the capacity of heirs, legatees and beneficiaries, as well as the powers of executors or administrators of the deceased estate. ${ }^{89}$ The Regulation further protects testators against reserved portion mechanisms in foreign member states without undermining such prescribed rules internally. ${ }^{90}$ Unfortunately, many a state refuses to apply a foreign limited property right or to apply a rule that is "manifestly incompatible" with the public policy of the forum. ${ }^{91}$

85 See the EU Council Regulation No 650/2012 (2012). Twenty-five countries have adopted the Regulation. See Nel 2018 TSAR 601-612.

86 The EU Succession Regulation was accepted by all EU states except Denmark and Ireland. See Nel 2018 TSAR for discussion on the EU Succession Regulation. See Oberle (Case C-20/17) 21 June 2018 CJEU, as well as Mahnkopf (Case C-558/16) 1 March 2018 CJEU.

Bost 2013 Emory Int'I L Rev 1150-1153.

88 The following information must be contained in the Certificate: the issuing court, the elements of fact and law and the date of issuance; all details of the deceased, including nationality and last habitual residence, and date and place of death; any applicable marriage contracts; the law applicable to succession in accordance with the EU Succession Regulation and the applicable reasons in fact and law; all elements giving rise to the rights and powers of heirs, legatees, executors, etc; the applicant's personal details and relationship with the deceased; details of heirs and legateees, their capacities and the assets and shares allocated to each of them, etc. See Ch VI of the EU Succession Regulation.

Bost 2013 Emory Int'l L Rev 1158-1160.

See arts 31 and 35 of the EU Succession Regulation. 
The fact that trusts, including testamentary trusts, have been excluded from the scope of the EU Succession Regulation is unfortunate as Europe-wide recognition would have contributed to legal certainty and a universal protection mechanism for minors and other vulnerable individuals. ${ }^{92}$ The same law could have been applied, or the testator could have been afforded the opportunity to elect the particular law which should govern a testamentary trust. ${ }^{93}$ While one cannot ignore the potential problems when a legal dispensation that is totally unfamiliar with the trust concept is confronted by it in a testamentary document, Dutta proposes that even where no choice of law can be inferred, the testamentary trust can be "transformed to its closest equivalent" under the applicable law of succession. ${ }^{94}$

How did the EU Succession Regulation affect the jurisdictions under discussion? In Maltese law a will must adhere to very specific formal rules. An ordinary public will must be notarised ${ }^{95}$ while a secret will must be either sealed and delivered to a notary who shall lodge it with a court of voluntary jurisdiction, or lodged directly with a court of law by the testator. ${ }^{96}$ The Maltese legislature has adapted its Civil Code to the EU Succession Regulation. ${ }^{97}$ Although Malta does not make use of probate or letters of executorship in the process of deceased estate administration, a civil court is competent to issue a European Certificate of Succession in all cases, but a notary shall do so only if all the beneficiaries are in agreement on the contents thereof. ${ }^{98}$ In Portugal practitioners allegedly experience difficulties with a lack of knowledge among clients, and in the case of an enforced application of the principle of habitual residence, also among states not bound by the EU Succession Regulation. The issuance of Certificates of Succession appears not to have been well developed there yet, although it

92 See para 13 of the Preamble of the EU Succession Regulation. Dutta 2009 Rabel Journal 592 in particular advises that testamentary trusts should be included in the Regulation. See Pfeiffer 2016 J Priv Int L 566-586, in which she comes to the conclusion that the EU Succession Regulation does not result in the level of legal certainty expected form it.

See Dutta 2009 Rabel Journal 593. Also see Nel 2018 TSAR 608-609. Compare in general Basedow and Dutta 2010 Rabel Journal 557-559, stating on 558 that the inclusion of testamentary trusts in the Regulations would be a "sensible" step. Dutta 2009 Rabel Journal 594. The unica charta will is a public will drawn up by spouses or civil partners in one instrument (combined will), but with a seperation of the assets of the two partners.

96 See arts 654-660 of the Civil Code Act XVI of 2015 of the Laws of Malta.

97 See in general Civil Code Act XVI of 2015.

See arts 958D and E of Civil Code Act XVI of 2015. 
is possible in theory. ${ }^{99}$ In the Netherlands the Regulation has been accepted and easily adapted to, as the Hague Succession Convention has been applied for the past two decades. This has also made it possible to choose the law of habitual residence in a last will and testament. ${ }^{100}$ The United Kingdom opted out of the EU Succession Regulation before Brexit took place. However, British citizens who are habitually resident in an EU member state at death, or hold assets there, may be affected by the Regulation.

\section{The Hague Convention on Matrimonial Property Regimes}

Succession law and matrimonial property law are closely related as the applicable matrimonial property regime and the resulting property relations are indicators of the ownership of assets and liabilities. ${ }^{101}$ It was therefore imperative to support the Hague Succession Convention of 1989 with an agreement on aspects of matrimonial property.

The Hague Convention on Matrimonial Property Regimes ${ }^{102}$ allows spouses to decide on the jurisdiction whose laws will apply to their property. The default rule in terms of the Convention is that the couple's first habitual residence after marriage governs their property. In the absence of a common habitual residence and a common nationality, their matrimonial regime is governed by the internal law of the state with which they are most closely connected. ${ }^{103}$ The Convention, however, does allow spouses to decide before marriage which jurisdiction will be applicable to their property - determined by nationality or habitual residence. ${ }^{104}$ The Convention has been ratified by only three states, one being the Netherlands, and it has been signed by a further two, one being Portugal. ${ }^{105}$ The Convention may apply even where neither the state of nationality nor that of habitual residence is a contracting state. ${ }^{106}$ The relevant law continues to apply to the property of the particular couple notwithstanding any change of their

Ruggeri, Kunda and Winkler Family Property and Succession 547. See Oberle (Case C-20/17) 21 June 2018 CJEU and Mannkopf (Case C-558/16) 1 March 2018 CJEU for the practical application of Succession Certificates.

Ruggeri, Kunda and Winkler Family Property and Succession 505.

See Van Erp 2007 EJCL 2-3.

Hague Convention on the Law Applicable to Matrimonial Property Regimes (1978) (the Hague Convention on Matrimonial Property Regimes), accepted on 14 March 1978, but it came into force on 1 September 1992 only.

See art 4 of the the Hague Convention on Matrimonial Property Regimes.

See art 3 of the the Hague Convention on Matrimonial Property Regimes.

France and Luxembourg also ratified it, while it was also signed but not ratified by Austria.

See art 2 of the the Hague Convention on Matrimonial Property Regimes. 
nationality or habitual residence, except if the applicable law is changed by express stipulation. ${ }^{107}$ It does not, however, apply to the succession rights of a surviving spouse and therefore has limited application as far as death is concerned, ${ }^{108}$ although it has been argued that the Convention provides more options for choice than the EU Matrimonial Property Regulations. ${ }^{109}$

Malta was never involved in the Convention, while Portugal took no steps to accede to it or to ratify it. In the Netherlands the default matrimonial property regime is that of community of property, ${ }^{110}$ but nuptial agreements may be entered into at any time during the marriage. ${ }^{111}$ The Convention is applicable to all marriages solemnised after 1 September 1992, and since 1 January 2018 a limited community of property regime applies to all marriages contracted in the Netherlands, except if excluded by way of a prenuptial agreement. ${ }^{112}$ As England and Wales have no matrimonial property regimes and did not traditionally enforce pre-nuptial agreements, the United Kingdom did not sign the Convention. ${ }^{113}$

\section{The EU Matrimonial Property and Registered Partnership Regulations}

Two further EU Regulations became operative on 29 January 2019. These were aimed at adopting common rules on jurisdiction, applicable law and the recognition and enforcement of decisions in the area of the property regimes of international couples, covering both marriages and registered partnerships in cases of death and divorce. ${ }^{114}$ The aspect of same-sex relationships was controversial in some states, which resulted in the Council adopting two twin regulations with a number of countries participating in the enhanced cooperation in the area of the property regimes of couples involved in registered partnerships. ${ }^{115}$ The regulations in question do not

\footnotetext{
107 See arts 7.7 and 13 of the the Hague Convention on Matrimonial Property Regimes.

108 See art 1 of the the Hague Convention on Matrimonial Property Regimes.

109 Ruggeri, Kunda and Winkler Family Property and Succession 495.

110 See Book 1, Title 7 BW. Since 1 January 2018 there have been two variants of the community of property regime - see arts 1:94 pars $4 B W$ and $2 a B W$.

111 See art 1:114 BW.

112 In terms of the new legislation only those assets and debts acquired during the marriage form part of the community of property.

113 See fn 12 above. Also see s 10(6) of the Family Law Act (Scotland), 1985, which includes an agreement between the parties as a "special circumstance" that needs to be considered in terms of ss 9(1) and 16(1).

114 See the Matrimonial Property Regulations 2016/1103 and 2016/1104.

115 The contents of the two Regulations are virtually the same. Nineteen countries have adopted the procedure of enhanced co-operation, namely Sweden, Belgium, Greece, Croatia, Slovenia, Spain, France, Portugal, Italy, Malta, Luxembourg,
} 
deal with succession matters, but provide international couples with some legal certainty regarding jurisdiction, and facilitate the recognition and enforcement of decisions on property matters given in another EU country. ${ }^{116}$ The parts on jurisdiction, recognition and enforceability apply only to authentic instruments (e.g. prenuptial agreements in member states) drafted on or after 29 January 2019, regardless of the date of the marriage: ${ }^{117}$ while matters on the applicable law are applicable on marriages concluded on or after 29 January 2019, except if the spouses have made a choice of law applicable to their matrimonial property regime before the applicable date. Election is limited to the law of the state where they or one of them is habitually resident at the time of the agreement or the state of nationality of either spouse or future spouse at the time of the agreement. They are not allowed to give to any state future prospective jurisdiction, conditional upon their future habitual residency. Where a court of a member state is seized in matters of the succession of a spouse pursuant to the $E U$ Succession Regulation, the courts of that state shall have jurisdiction to rule on matters of the matrimonial property regime arising in connection with that succession case. ${ }^{118}$

For South African drafters of wills for parties who may be affected by these regulations, it will in future not be sufficient for forum consideration to determine only habitual residence, nationality or other connections the spouses may have with any EU jurisdiction. A critical question is also whether after 29 January 2019 they have entered into a matrimonial property regime in a member state. ${ }^{119}$ The content of such a contract, its applicable law and confirmation of registration should be determined. ${ }^{120}$ Couples may agree to change in writing (or electronically) the law applicable to their matrimonial property regime to their (or one of their) habitual residence(s) at the time of the agreement, or to the law of a state of nationality of either spouse at the time the agreement is concluded. ${ }^{121}$

Germany, Czech Republic, the Netherlands, Austria, Bulgaria, Finland, Cyprus and Estonia. See Wysocka-Bar 2019 ERA-forum 187-200.

116 See Kubicka (Case C-218/16) 12 October 2017 CJEU.

117 See arts 58, 59 and 69 of the Matrimonial Property Regulations 2016/1103 on the acceptance and enforceability of authentic instruments.

118 Article 4 of the Matrimonial Property Regulations.

119 Article 3(1)(f) of the Matrimonial Property Regulations 2016/1103 defines a "member state of origin" as the state "in which the decision has been given, the authentic instrument drawn up, or the court settlement approved or concluded."

120 Equivalent principles are applicable to civil partnerships in terms of the Registered Partnership Regulations 2016/1104.

121 Articles 22(1) and 23 of the Matrimonial Property Regulations 2016/1103. Any prescribed formal requirements in the law of the state of habitual residence or 
Two of the important principles applied by the Regulations are that of universal application and that of unity of the applicable law. In terms of universal application, the designated law applies even if it is not the law of a member state. For example: in the case of a couple, one a Portuguese citizen and the other from England, habitually residing in South Africa after their marriage, South African law will apply to their matrimonial property regime. ${ }^{122}$ The unity of the applicable law dictates that, if the couple has not concluded an agreement on the choice of applicable law, South African law will apply to all their movable and immovable assets - even those located in Portugal and England. ${ }^{123}$ To facilitate the management of their property, spouses may at any stage choose the law applicable to their matrimonial property regime, regardless of the nature or location of the property - even if it is located in a third state. They may make an election from among the jurisdictions with which they have close links because of habitual residence or nationality. ${ }^{124} \mathrm{~A}$ couple, both South African nationals, with assets located in Spain and Italy respectively, and after their marriage habitually resident in Germany may elect either South African or German law to be applicable to their matrimonial property regime. It is ideal, and indeed an intention of the Regulations, to enable married couples to have their various related procedures handled by the courts of the same state. Ideally, should couples seek to concentrate the jurisdiction on their matrimonial property regime in the same jurisdiction, they have elected to deal with their respective successions in accordance with the EU Succession Regulation. ${ }^{125}$

It is important to note the practical impact of the Regulations on the substantive laws of the jurisdictions under discussion. Maltese law provides couples with three options in arranging their matrimonial property, namely a community of acquests regime, which is the default position; community of residue; and separation of administration. ${ }^{126}$ Spouses cannot vary their legal order of succession except by way of testamentary dispositions allowed by law. ${ }^{127}$ Malta also participates in the enhanced cooperation with regard to

nationality must be complied with. Art 26 regulates the applicable law in the absence of choice by the parties.

122 See art 20 of the Matrimonial Property Regulations 2016/1103.

123 Article 21 of the Matrimonial Property Regulations 2016/1103. See note (43) of the introductory notes to the Regulations.

124 See note (45) of the introductory notes to the Matrimonial Property Regulations 2016/1103.

125 See notes (32) and (33) of the introductory notes to the Matrimonial Property Regulations 2016/1103.

126 See arts 1320 and 1333 of the Maltese Civil Code.

127 See arts 1237 and 1238 of the Maltese Civil Code. 
the two matrimonial property regulations. ${ }^{128}$ The Portuguese Civil Code provides for three types of matrimonial property regimes, and in addition thereto the freedom to establish antenuptial pacts by creating an atypical property regime based on the three models or a combination thereof. ${ }^{129}$ The default position is communion of acquired assets; ${ }^{130}$ general community of assets; and separation of assets. Portugal is also a participating state as far as the EU Regulations are concerned. Some concerns have been raised, however, regarding issues such as the preferential inheritance attributions to the spouse of the family home and its contents, and conflicts in the case of a different regime from that in force during the marriage. ${ }^{131}$ The Netherlands participates in the enhanced cooperation and, as it has been one of only a few jurisdictions to have been party to the Hague Convention on Matrimonial Property Regimes, it has provided for a choice of law for a long time. ${ }^{132}$ The United Kingdom (England, Wales and Northern Ireland) has no matrimonial property regime and in principle marriage does not have any proprietary effect. ${ }^{133}$ Although the Regulations were finalised before Brexit, the United Kingdom did not participate in the enhanced co-operation thereof.

\section{Conclusion}

As stated at the outset of this article, the focus was on the impact of financial and asset globalisation on South African citizens working, investing or living abroad, often with the intention to acquire a second passport, dual citizenship or even permanent residency. Estate planners and testators with assets and liabilities in more than one jurisdiction must be aware of the legal realities and potential pitfalls when drafting a will. A testator may leave his surviving spouse in a financially vulnerable position if his last wishes cannot be adhered to due to non-compliance with or ignorance of the rules of a particular legal system or international law. The internationalisation not only of individuals and couples but also of succeeding generations and family

\footnotetext{
128 Council Decision EU 2016/954 of 9 June 2016. See footnote 115 for more on the aspect of enhanced cooperation.

129 See Ruggeri, Kunda and Winkler Family Property and Succession 530.

130 See art 1717 of the Portuguese Civil Code.

131 See arts 2103A and 1719 of the Portuguese Civil Code.

132 Matrimonial property regimes are regulated by a 1:93 and a 1:114 BW.

133 Scotland has a modified separate property system, as per s 24 of the Family Law Act (Scotland), 1985, in terms whereof a spouse has occupancy rights in the matrimonial home, and applies the principle of "fair sharing", as well as protective rights for a spouse on the death of the first-dying.
} 
groups complicates the smooth and least-infringing transfer of assets to successors-in-title.

Despite many attempts over several decades to harmonise private international law with regard to wills, succession, deceased estates and matrimonial property regimes, not much has changed for testators with cross-border estates. The world itself has changed and the successful harmonisation of family and succession law needs to accommodate the modern concept of the family. ${ }^{134}$

A bird's eye view has been given In this article of the most important international instruments in the context of the South African testator. Among the Hague Conventions only the one on testamentary dispositions and to a lesser extent the one on trusts have any real impact on the development of private international law, although in a narrower scope of jurisdictions the recent regulatory initiatives by the European Union successfully involve a much larger legal audience. Many South African testators have assets and family in EU destinations, and increasingly so, without necessarily taking into consideration the legal intricacies thereof at death.

As far as the EU Succession Regulation is concerned, with habitual residence as the key connecting factor, the power granted to the testator to elect the applicable law is a positive aspect which should be utilised by will drafters and testators. Probate and the appointment of foreign executors should be less cumbersome and should empower testators to have their nominated executors appointed in non-member states. ${ }^{135}$ Executors in nonmember states such as South Africa can unfortunately not benefit from the issuance of a European Certificate of Succession. ${ }^{136}$

The particular matrimonial property regime and the succession consequences of the estates of a couple are interwoven. If due consideration is given by international couples, the Matrimonial Property Regulation has the potential to provide them with much more legal certainty than before, both in recognising and in enforcing their contractual commitment. The election of the applicable law is again a cornerstone of the effective implementation of the instrument. Both testators and drafters

\footnotetext{
134 Rešetar 2008 EJCL $1-18$ submits that an interdisciplinary approach is necessary to successfully harmonise and unify matrimonial property systems in a European context.

135 See arts 29(1)-(3) of the EU Succession Regulation.

136 See art 62 of the EU Succession Regulation. They will still have to rely on an Apostille in terms of the Hague Convention on the Abolishment of the Requirements for Foreign Public Documents (1961), which Convention SA did accede to.
} 
of wills must become more aware of the critical role of nuptial agreements in the estate planning process. The inclusion of the principle of universal application strengthens the value of prenuptial agreements, while the unity of the applicable law contributes to legal certainty.

When advising couples on prenuptial agreements, estates and wills, not only fiduciary practitioners but also attorneys and notaries must know and understand the contents and consequences of these regulations. The evolution of family and fiduciary law has for centuries taken place in the confinement of moral, legal and social environments closely linked to the dominant worldviews at the time. ${ }^{137}$ Internationalisation, however, demands critical, less doctrinal thinking in overcoming the practical conundrums of multi-jurisdictional estates. One potential avenue is the replacement of the sentimental protectionism of traditional family and fiduciary law with pragmatic and commercial solutions. ${ }^{138}$ An example would be the assimilation of contracts and wills "into a single genus of legal doctrine", as has been advocated in the past. ${ }^{139}$ The international business community has come much further than family and fiduciary lawyers in synthesising the applicable laws. ${ }^{140}$ As has been advocated by Hirsch, albeit in a different context: "inheritance scholars must learn to think outside the coffin". ${ }^{141}$ While governments, legislators and courts shall continue to regulate the international fiduciary and succession law environment, practitioners need to be able to apply such regulatory mechanisms in the best interest of their clients.

To summarise, the South African fiduciary advisor should at least consider the following when analysing an estate for a client exposed to more than one jurisdiction: the location and value of all assets; the location of all heirs and legatees and their marital status, and, in the case of minors, the enforceability of a testamentary trust in the particular jurisdiction; the substantive law of succession in each and every jurisdiction exposed to; the tax implications for offshore beneficiaries receiving benefits from a deceased estate or a testamentary or living trust; the contents of the prenuptial agreement and its applicability in all jurisdictions where assets

\footnotetext{
137 See Gold and Miller Philosophical Foundations of Fiduciary Law 11.

138 Rešetar 2008 EJCL 18 submits that the system of community of property has served as an "instrument of artificial corrective justice of factual inequality of spouses." See Hirsch 2011 Minn L Rev 2251 for some compelling arguments.

140 It has been suggested that a consolidated approach to the regulation of private international law is taken in the EU context to clarify ambiguities in the lex societas, the lex contractus, the lex delicti, etc, to establish a "unity of the legal order". See EU Study on the Law Applicable to Companies 349.

141 Hirsch 2011 Minn L Rev 2253.
} 
are located; the applicability of one world-wide will or separate wills dealing with assets in different jurisdictions; the enforceability in a particular jurisdiction of a will drafted in South Africa; the election of a particular habitual residence; the election of the applicable law; the particular process of estate administration in each jurisdiction and whether a probate system exists or not; the tax consequences at death in the applicable foreign jurisdictions and the contents of any double-tax agreement with South Africa; and the applicability of any international conventions.

To conclude, South African drafters of wills for parties who may be affected by the EU Regulations should determine all possible connecting factors, indicate habitual residence, consider proper forum nomination, and investigate the possibility that the parties may have entered into a matrimonial property regime in a member state. ${ }^{142}$

\section{Bibliography}

\section{Literature}

Basedow and Dutta 2010 Rabel Journal

Basedow $J$ and Dutta A "Comments on the European Commission's Proposal for a Regulation of the European Parliament and of the Council on Jurisdiction, Applicable Law, Recognition and Enforcement of Decisions and Authentic Instruments in Matters of Succession and the Creation of a European Certificate of Succession" 2010 Rabel Journal 522-720

Bost 2013 Emory Int'l L Rev

Bost $J$ "Nothing Certain about Death and Taxes (and Inheritance): European Union Regulation of Cross-Border Successions" 2013 Emory Int'l L Rev 1145-1174

Braun "Will-Substitutes"

Braun A "Will-Substitutes in England and Wales" in Braun A and Röthel A (eds) Passing Wealth on Death: Will-Substitutes in Comparative Perspective (Hart Oxford 2016) 51-77

142 If in the affirmative, the content of such a contract, its applicable law and confirmation of registration should be determined. Equivalent principles are applicable to civil partnerships in terms of the Registered Partnership Regulations 2016/1104. See art 3(1)(f) of the Matrimonial Property Regulations 2016/1103, as well as arts 22(1), 23 and 26. 
Coutinho and Piçarra "Portugal"

Coutinho FP and Piçarra N "Portugal: The Impact of European Integration and the Economic Crisis on the Identity of the Constitution" in Albi A and Bardutzky S (eds) National Constitutions in European and Global Governance: Democracy, Rights, the Rule of Law (TMC Asser The Hague 2019) 591-639

Dutta 2009 Rabel Journal

Dutta A "Succession and Wills in the Conflict of Laws on the Eve of Europeanisation" 2009 Rabel Journal 547-606

Ernst \& Young Worldwide Estate and Inheritance Tax Guide

Ernst \& Young Worldwide Estate and Inheritance Tax Guide (Ernst \& Young London 2018)

EU Study on the Law Applicable to Companies

European Union Study on the Law Applicable to Companies: Final Report (European Union Luxembourg 2016)

Faulconbridge and Beaverstock "Globalization"

Faulconbridge JR and Beaverstock JV "Globalization: Interconnected Worlds" in Clifford NJ (ed) Key Concepts in Geography (Thousand Oaks London 2008) 331-343

Filesia 2020 WPNR

Filesia KR "De Rechtskeuze in het Interregionaal Erfrecht Versus de Legitieme Portie (1)" 7 Maart 2020 WPNR 184-188

Geçer Practical Matter Test

Geçer AE A Practical Matter Test: The Concept of Beneficial Ownership in International Tax Law (Lambert Academic Publishing Chisinau 2014)

Gold and Miller Philosophical Foundations of Fiduciary Law

Gold AS and Miller PB Philosophical Foundations of Fiduciary Law (Oxford University Press Oxford 2016)

Greene Trusts, Foundations and Fiduciary Structures

Greene DS Trusts, Foundations and Fiduciary Structures: Portugal $2^{\text {nd }}$ ed (euroFinesco Lisbon 2018)

Hansmann and Mattei 1998 NYU L Rev

Hansmann $\mathrm{H}$ and Mattei $\mathrm{U}$ "The Functions of Trust Law: A Comparative Legal and Economic Analysis" 1998 NYU L Rev 434-479 
Hayton 2008 DNotl, Les Successions Internationales dans I'UE

Hayton DJ "Determination of the Objectively Applicable Law Governing Succession to Deceased Estates" 2008 DNotl, Les Successions Internationales dans I'UE 359-371

Hayton $2016 \mathrm{~J}$ Priv Int L

Hayton DJ "Reflections on the Hague Trusts Convention after 30 Years" 2016 J Priv Int L 1-25

Hayton and Underhill Law Relating to Trusts and Trustees

Hayton DJ and Underhill A Law Relating to Trusts and Trustees $15^{\text {th }}$ ed (Butterworths London 1995)

Hayton et al 2007 Law of Trusts and Trustees

Hayton DJ et al Law of Trusts and Trustees $17^{\text {th }}$ ed (Butterworths London 2007)

Hirsch 2011 Minn L Rev

Hirsch AJ "Freedom of Testation / Freedom of Contract" 2011 Minn L Rev 2180-2253

Nel Business Trust

Nel E The Business Trust and It's Role as an Entity in the Financial Environment (LLD-thesis NMMU 2012)

Nel 2018 TSAR

Nel E "The Impact of the European Union's Succession Regulation on a Multi-Jurisdictional Estate" 2018 TSAR 601-612

Nel 2019 TSAR

Nel E "Testamentêre Trusts en die Nederlandse Testamentair Bewind - 'n Regsvergelykende Ondersoek" 2019 TSAR 713-727

O'Brien Conflict of Laws

O'Brien J Conflict of Laws $2^{\text {nd }}$ ed (Cavindish London 1995)

Pfeiffer $2016 \mathrm{~J}$ Priv Int $L$

Pfeiffer M "Legal Certainty and Predictability in International Succession Law" 2016 J Priv Int L 566-586

Phipps "Wills and Estates"

Phipps O "Wills and Estates: The British Isles" Presentation for Fiduciary Institute of Southern Africa (March 2015) 
Private Client Tax Committee The Netherlands

Private Client Tax Committee The Netherlands: International Estate Planning Guide 8/2020 (Loyens and Loeff NV Lonon 2020)

Rešetar 2008 EJCL

Rešetar B "Matrimonial Property in Europe: A Link between Sociology and Family Law" 2008 EJCL 1-18

Ruggeri, Kunda and Winkler Family Property and Succession

Ruggeri L, Kunda I and Winkler S (eds) Family Property and Succession in EU Member States: National Reports on the Collected Data (University of Rijeka Rijeka 2019)

Sänchez 2015 Cuadernos de Derecho Transnational

Sänchez RL "Testamentary Trusts in English Law: An Introductory Approach" 2015 Cuadernos de Derecho Transnational 96-111

SARB Currency and Exchange Guidelines

South African Reserve Bank Currency and Exchange Guidelines for Business 2020-02-14 (South African Reserve Bank Pretoria 2020)

Schulze 2001 CILSA

Schulze $\mathrm{H}$ "Conflicting Laws of Conflict in Cases of International Succession" 2001 CILSA 34-47

Swire 2019 Step Journal

Swire H "United States" June 2019 Step Journal 30-31

Van der Merwe, Rowland and Cronje Suid-Afrikaanse Erfreg

Van der Merwe NJ, Rowland CJ and Cronje MB Die Suid-Afrikaanse Erfreg $6^{\text {th }}$ ed (JP van der Walt Pretoria 1990)

Van Erp 2007 EJCL

Van Erp S "New Developments in Succession Law" 2007 EJCL 1-20

WTO World Trade Report 2008

World Trade Organisation World Trade Report 2008: Trade in a Globalizing World (World Trade Organisation Geneva 2008)

Wysocka-Bar 2019 Era-forum

Wysocka-Bar A "Enhanced Cooperation in Property Matters in the EU and Non-Participating Member States" 2019 ERA-forum 187-200 
Xuereb "Constitution of Malta"

Xuereb PG "The Constitution of Malta: Reflections on New Mechanisms for Synchrony of Values in Different Levels of Governance" in Albi A and Bardutzky $S$ (eds) National Constitutions in European and Global Governance: Democracy, Rights, the Rule of Law (TMC Asser The Hague 2019) $141-143$

\section{Case law}

Brack v Brack [2018] EWCA Civ 2862

JW v Williams-Ashman 20204 SA 567 (WCC)

Kubicka (Case C-218/16) 12 October 2017 CJEU

Mahnkopf (Case C-558/16) 1 March 2018 CJEU

Oberle (Case C-20/17) 21 June 2018 CJEU

Radmacher v Granatino [2010] UKSC 42

Versteegh v Versteegh [2018] EWCA Civ 1050

\section{Legislation}

\section{England}

Inheritance and Trustees' Powers Act, 2014

\section{Malta}

Civil Code Act XVI of 2015

Constitution of Malta, 1964

Recognition of Trusts Act, 1994

Trust and Trustees Act 35 of 1988, ch 331 of the Laws of Malta

Trusts and Trustees Act, 2004

Trusts and Trustees (Amendment) Act XI of 2014

\section{Netherlands}

Burgerlijk Wetboek 


\section{Portugal}

Civil Code, 1967

Civil Registry Code

Code of Civil Procedure

Land Registry Code

Scotland

Family Law Act (Scotland), 1985

Requirements of Writing Act, 1995

\section{South African}

Administration of Estates Act 66 of 1965

Constitution of the Republic of South Africa, 1996

Law of Succession Amendment Act 43 of 1992

South African Citizenship Act 88 of 1995

Wills Act 7 of 1953

Wills Amendment Act 41 of 1965

\section{United Kingdom}

Recognition of Trusts Act, 1987

Trustee Act 29 of 2000

Wills Act 26 of 1837

International instruments

Basel Convention on the Establishment of a Scheme of Registration of Wills (1972)

Council Decision EU 2016/954 of 9 June 2016 
European Convention on the Law Applicable to Contractual Obligations (1980) (the Rome Convention)

EU Council Regulation No 650/2012 (2012)

EU Council Regulation No 2016/1103, Implementing Enhanced Cooperation in the Area of Jurisdiction, Applicable Law and the Recognition and Enforcement of Decisions in Matters of Matrimonial Property Regimes (2016)

EU Council Regulation No 2016/1104, Implementing Enhanced Cooperation in the Area of Jurisdiction, Applicable Law and the Recognition and Enforcement of Decisions in Matters of the Property Consequences of Registered Partnerships (2016)

Hague Convention Concerning the International Administration of the Estates of Deceased Persons (1973)

Hague Convention on the Abolishment of the Requirements for Foreign Public Documents (1961)

Hague Convention on the Conflict of Laws Relating to the Form of Testamentary Dispositions (1961)

Hague Convention on the Law Applicable to Succession to the Estates of Deceased Persons (1989)

Hague Convention on the Law Applicable to Matrimonial Property Regimes (1978)

Hague Convention on the Law Applicable to Trusts and on their Recognition (1985)

UNIDROIT Convention (1940)

\section{Internet sources}

ENRWA 2010 http://www.arert.eu/IMG/pdf/etatdeslieux-2010-03-10-EN.pdf European Network of Registers of Wills Association 2010 "Europe Wills" Programme: Status Report on Schemes of Wills Registration and Search in Europe http://www.arert.eu/IMG/pdf/etatdeslieux-2010-03-10-EN.pdf accesed 10 August 2021 
European Commission 2005 https://eur-lex.europa.eu/legalcontent/EN/TXT/PDF/?uri=CELEX:52005DC0065\&from=en

European Commission 2005 Green Paper on Succession and Wills $\operatorname{COM}(2005) \quad 65$ final https://eur-lex.europa.eu/legalcontent/EN/TXT/PDF/?uri=CELEX:52005DC0065\&from=en accessed 10 August 2021

Law Reform Commission Report on the Hague Convention Law Reform Commission Report on the Hague Convention on the Law Applicable to Succession to the Estates Of Deceased Persons (Law Reform Commission Dublin 1989)

South Africa - New York Date Unknown http://www.southafricanewyork.net/homeaffairs/dualcitinfo.htm

South Africa - New York Date Unknown Dual Citizenship Information http://www.southafrica-newyork.net/homeaffairs/dualcitinfo.htm accessed 11 November 2019

\section{List of Abbreviations}

BW

CILSA

CJEU

EJCL

Emory Int'l L Rev

ENRWA

EU

J Priv Int L

Minn L Rev

NYU L Rev

Rabel Journal

SARB

TSAR

WPNR

WTO
Burgerlijk Wetboek

Comparative and International Law Journal of Southern Africa

Court of Justice of the European Union Electronic Journal of Comparative Law

Emory International Law Review

European Network of Registers of Wills Association

European Union

Journal of Private International Law

Minnesota Law Review

New York University Law Review

The Rabel Journal of Comparative and International Private Law

South African Reserve Bank

Tydskrif vir die Suid-Afrikaanse Reg

Weekblad voor Privaatrecht, Notariaat en Registratie

World Trade Organisation 